\title{
Transient erosion in the Valencia Trough turbidite systems, NW Mediterranean Basin
}

6

7

37 Keywords: Submarine canyons, turbidity currents, long-profiles, knickpoints, transient 38

\author{
David Amblas ${ }^{\mathrm{a}}$, Thomas P. Gerber ${ }^{\mathrm{b}}$, Miquel Canals ${ }^{\mathrm{a},{ }^{,}}$, Lincoln F. Pratson ${ }^{\mathrm{c}}$, Roger \\ Urgeles $^{d}$, Galderic Lastras ${ }^{a}$, Antoni M. Calafat ${ }^{a}$
} ${ }^{\mathrm{a}}$ GRC Geociències Marines, Facultat de Geologia, Universitat de Barcelona, E-08028 Barcelona, Spain

${ }^{b}$ Department of Geology, University at Buffalo, NY 14260 Buffalo, USA 'Division of Earth \& Ocean Sciences, Duke University, NC 27708 Durham, USA ${ }^{\mathrm{d} D e p t . ~ G e o l o g i a ~ M a r i n a, ~ I n s t i t u t ~ d e ~ C i e ̀ n c i e s ~ d e l ~ M a r, ~ C S I C, ~ E-08003 ~ B a r c e l o n a, ~ S p a i n ~}$

*Corresponding author. Tel: (+34)934021360; Fax: (+34)934021340

E-mail address: miquelcanals@ub.edu (M. Canals) 
Submarine canyons can efficiently drain sediments from continental margins just as river systems do in subaerial catchments. Like in river systems, submarine canyons are often arranged as complex drainage networks that evolve from patterns of erosion and deposition. In the present paper we use a morphometric analysis of submarine canyonchannel long-profiles to study the recent sedimentary history of the Valencia Trough turbidite system (VTTS) in the NW Mediterranean Sea. The VTTS is unique in that it drains sediment from margins with contrasting morphologies through a single "trunk" conduit, the Valencia Channel. The Valencia Channel has been active since the late Miocene, evolving in response to Plio-Quaternary episodes of erosion and deposition. The integrated analysis of long-profiles obtained from high-resolution bathymetric data across the entire turbidite system shows evidence for transient canyon incision in the form of knickpoints and hanging tributaries. Multiple factors appear to have triggered these periods of incision. These include a large debris flow at 11,500 yr BP that disrupted the upper reaches of the VTTS and glacio-eustatic lowstands that forced shifting of sediment input to the VTTS. Based on these inferences, long-term time-averaged incision rates for the Valencia Channel have been estimated. The evidence we present strongly suggests that Foix Canyon has played a key role in the drainage dynamics of the VTTS in the past.

60

This study builds conceptually on a recent modeling study that provides a morphodynamic explanation for the long-term evolution of submarine canyon thalweg 63 profiles. The procedure and results from this work are of potential application to other 64 submarine sediment drainage systems, past and present, including those containing midocean type valleys like the Valencia Channel. 
69 Submarine canyons are one of the most intriguing features of Earth's surface. They are some of Earth's largest erosive landforms and the main transport path for sediment accumulating in the deep ocean basins. Not surprisingly, submarine canyons have been a main focus of study for the marine science community. Although submarine canyons were first recognized in the 19th century (Dana, 1863), they were not mapped in detail until the late 20th century following advances in geophysical technology. Today we have submarine canyon images with a resolution comparable to subaerial DEMs, which has allowed us to deepen our understanding of canyon form and evolution.

Though there is still some controversy surrounding submarine canyon genesis (Pratson et al., 2009, and references therein), it is widely accepted that they evolve and grow from the action of sediment gravity flows, mainly turbidity currents (Shepard, 1981), but also other flows like dense shelf water cascades (Canals et al., 2006). The long-term effect of gravity flows passing through a canyon shapes its morphology. Thus canyon morphologic variability is largely due to differences in flow-related factors, such as the characteristic flow size, density and grain size (Pratson et al., 2000; Kneller, 2003; Gerber et al., 2009). Together, these factors and the overall basin setting determine the canyon morphodynamics.

A very useful canyon measure for inferring morphodynamic processes is the alongthalweg depth profile (i.e. canyon long-profile). Like in rivers, the long-profile of canyons tends to display smooth curvature despite the topographic irregularity of the adjacent seafloor. This observation has motivated studies aimed at reconstructing flow properties from canyon and channel long-profiles that are assumed to be in steady-state with an average fluid and sediment discharge (e.g. Pirmez et al., 2000; Kneller, 2003; Pirmez and Imran, 2003; Mitchell, 2005a; Gerber et al., 2009). In addition, submarine canyons show discontinuities in their long profile that resemble widely observed subaerial knickpoints. In river basins, knickpoints are generally interpreted as evidence for downstream base level fall, and their form has been used to infer erosion laws (i.e. detachment- vs. transportlimited erosion) governing upstream migration (Howard et al., 1994; Whipple and Tucker, 2002). Submarine knickpoints have been shown to initiate where tectonic motion 100 displaces the seafloor (e.g. Mitchell, 2006) and where channel levees are breached (e.g. 101 Pirmez et al., 2000). However, there is no consensus on the form of a turbidity-current 102 transport law governing knickpoint migration (Mitchell, 2006; Gerber et al., 2009) or on 103 whether changes in an ultimate submarine "base level" can generate knickpoints (e.g. 
104 Adeogba et al., 2005). Moreover, while subaerial studies of knickpoints have been 105 conducted at the scale of an entire drainage network (Crosby and Whipple, 2006), most

106 submarine examples have been documented over a single reach.

108 Classically, the sedimentary record of submarine basins has been described using an 109 analysis of depositional bodies, especially outer-shelf prograding clinoforms (e.g. 110 Mitchum et al., 1977; Nittrouer et al., 1986; Cattaneo et al., 2004; Rabineau et al., 2005) 111 and deep-sea fans (e.g. Normark, 1970; Bouma et al., 1986; Palanques et al., 1994; 112 Covault and Romans, 2009). Morphologic anomalies in canyon long-profiles also contain 113 valuable information about previous equilibrium conditions and can be used to unveil the 114 long-term sedimentary history either in single canyons or in submarine valley networks. In 115 the present study we use these anomalies to address the long-term evolution of the entire 116 Valencia Trough turbidite system (VTTS), defined here as the submarine drainage 117 extending from the saddle of the Eivissa Channel, at the southern end of the Valencia 118 Trough, to the Algero-Balearic abyssal plain, at its northern terminus. Our approach is 119 similar to the subaerial drainage basin analysis recently done for the Colorado River 120 (Cook et al., 2009).

122 Methods for determining terrestrial erosion rates (e.g. cosmogenic radionuclides, fission 123 tracks, He dating) are generally not available in the submarine environment (Mitchell et 124 al., 2003), although recent studies have used optically stimulated luminescence (OSL; 125 e.g. Olley et al., 2004) to date sand grains in modern deep-water transport systems (e.g. 126 Boyd et al., 2008). In this paper we focus on detailed long-profile bathymetry compiled across the large VTTS to roughly estimate maximum time-averaged channel erosion rates. To do this we combine the shape of the network's smooth long-profiles with that of two prominent knickpoints to estimate the depth of entrenchment in the Valencia

130 Channel. We then consider possible triggers for the entrenchment and consequent 131 knickpoint initiation, focusing on processes in both the upper and lower portions of the 132 drainage network. By reconstructing the dynamics of channel adjustment we assess the 133 extent to which turbidite channels adjust their morphology and relief following 134 perturbations to the drainage network.

\section{Study Area} The Valencia Channel is the main conduit through which sediment is transported along 140 the deep Catalano-Balearic Basin, i.e. the portion of the Western Mediterranean Basin 
141 extending from the Balearic Archipelago to the southeast with the Iberian mainland as its 142 northwestern limit (Palanques and Maldonado, 1985; Alonso et al., 1991; Canals et al., 143 2000; Amblas et al., 2006). This deep-sea channel (Fig. 1), classified by Canals et al. 144 (2000) as a mid-ocean type valley, routes sediment from a network of submarine canyons 145 and canyon-valley systems crossing the Ebro and Catalan margins, and also from 146 localized large unconfined landslides (Alonso et al., 1991; Canals et al., 2000, Lastras et 147 al., 2002; Amblas et al., 2006). The 430 km long Valencia Channel starts approximately 148 at $1600 \mathrm{~m}$ water depth and terminates on the Valencia Fan (Palanques and Maldonado, 149 1985), which lies on the northernmost part of the Algero-Balearic abyssal plain at about $1502800 \mathrm{~m}$ water depth (Fig. 1).

152 Almost the entire length of the Valencia Channel follows the Valencia Trough axis, and 153 thus parallels the bordering Iberian and Balearic continental margins. The Valencia 154 Trough is one of the extensional sub-basins that define the northwestern Neogene Mediterranean rift system (Maillard and Mauffret, 1999). The trough, Late Oligocene-

156 Early Miocene in age, is delineated by NE-SW oriented horsts and grabens (Roca et al., 157 1999). Incision in the Valencia Trough may have originated under subaerial conditions during the Messinian salinity crisis (Cita et al., 1978; Alonso et al., 1995; Maillard et al., 2006). Some of the submarine valleys draining into the Valencia Channel are also of Messinian origin, though there is not a one to one relationship between Messinian Canyons and presentday Canyons (e.g. Urgeles et al., 2010). Other canyons appear to have formed during Plio-Quaternary lowstands and some appear to coincide with tectonic faults (Alonso et al., 1991, 1995; Berné et al., 1999; Amblas et al., 2004, 2006; Kertznus and Kneller, 2009; Petter et al., 2010). However, the current shape of the VTTS reflects submarine erosion and deposition by sediment gravity flows during Pliocene and Quaternary times (Palanques et al., 1994; Alonso et al., 1995).

170 Following the margin morphologic analysis performed by Amblas et al. (2006), we define the Valencia Channel upper course as the Ebro Margin reach, the middle course as the South Catalan Margin reach, and the lower course as the segment downstream from Blanes Canyon junction, marking the boundary with the North Catalan margin (Figs. 1 and 2). This classification slightly differs geographically to that proposed by Alonso et al. (1995) before comprehensive multibeam bathymetry data from the area were available. The Valencia Channel is unique in that it incorporates sediment output from two distinctly different sediment routing systems in a semi-confined basin. The upper course of the 
Valencia Channel is fed by numerous, relatively small canyon-channel systems (i.e. the

179 Ebro turbidite system) initiating on the outermost section of the wide Ebro constructional

180 shelf (60-80 km) or on the upper slope (Canals et al., 2000; Kertznus and Kneller, 2009).

181 On the other hand, the middle course is fed by a few large canyons incised into the rather

182 narrow South Catalan shelf and in a smooth slope, with evidence for significant sediment

183 bypassing to the Valencia Channel (Amblas et al., 2006). This contrast between

184 neighbouring margins has motivated the development of a morphodynamic model

185 describing the controls on the long-profile shape of submarine canyons (Gerber et al., 186 2009).

\section{Submarine canyon-channel morphology}

191 During the last decade several cruises performed extensive multibeam surveying in the 192 Catalano-Balearic Basin, which provided an almost complete image of the VTTS. Survey 193 and data set characteristics are thoroughly described in Amblas et al. (2006). The data 194 resolution $(50 \mathrm{~m}$ ) allows us to characterize not only the largest sediment conduits (i.e. 195 submarine canyons and canyon-channel systems) in the basin but also details of their morphology, including thalwegs, axial incisions, canyon walls, levees and terraces.

198 As the major focus of our study, we extracted the long-profiles of major canyons feeding 199 the Valencia Channel by tracing thalwegs on the bathymetry. The modern VTTS is bound 200 by Orpesa Canyon (the southernmost modern tributary of the Valencia Channel) and 201 Blanes Canyon (the northernmost modern tributary of the Valencia Channel) (Fig. 1). 202 These long-profile elevation-distance plots are shown together with the Valencia Channel 203 profile in Fig. 2a, which illustrates the entire VTTS up to its distal end (i.e. Valencia Fan). 204 In general, long-profile curvature is upward concave (i.e. decreasing in downslope 205 direction), though there are slight differences between them.

207 Blanes Canyon (length: $184 \mathrm{~km}$; sinuosity: 1.47) is the northernmost of the Valencia 208 Channel tributaries and is incised up to $1500 \mathrm{~m}$ into the Catalan margin continental shelf. 209 The canyon head parallels the nearby (less than $4 \mathrm{~km}$ ) coastline and the upper course is 210 characterized by steep (more than $2^{\circ}$ ) gullied walls (Lastras et al., 2011). The structural 211 grain beneath the base of the slope may be responsible for the meandering morphology 212 of the lower course flat-floored channel (Amblas et al., 2006). Blanes Canyon joins the 213 lower Valencia Channel segment at approximately $2600 \mathrm{~m}$ water depth (Fig. 3f). The 214 Arenys (length: 76 km; sinuosity 1.06) and Besòs (length: 79 km; sinuosity: 1.03) canyons 
215 are mostly restricted to the slope and rise and display a linear NW-SE trend. Both 216 canyons are incised up to $470 \mathrm{~m}$ into the Catalan margin slope. Canyon-walls have few 217 gullies and the thalwegs are almost flat-floored with nearly constant width. Arenys and 218 Besòs canyons converge immediately above the Valencia Channel and join it as a wide 219 single valley in $2380 \mathrm{~m}$ of water depth (Fig. 3e). Foix Canyon (97 km long) is located 220 south of the Llobregat Delta and is the southernmost of the Catalan Margin canyons. Its 221 upper course consists of two similar highly sinuous arms that merge at $1430 \mathrm{~m}$ depth. 222 The southern arm hangs $220 \mathrm{~m}$ above the northern one, indicating more recent activity of 223 the latter. Total sinuosity of the canyon calculated from its northern arm is 1.23 , which is 224 probably influenced by tectonic faults beneath its upper course (Amblas et al., 2006). 225 Maximum canyon wall gradients (up to $23^{\circ}$ ) and down-cutting (up to $480 \mathrm{~m}$ ) are observed 226 in the upper course. The lower course of Foix Canyon becomes wider and flat floored and 227 joins the Valencia Channel at $2180 \mathrm{~m}$ water depth (Fig. 3d). Vinaròs (length: 78 km; 228 sinuosity: 1.24), Hirta (length: $74 \mathrm{~km}$; sinuosity: 1.24) and Orpesa (length: $68 \mathrm{~km}$; 229 sinuosity: 1.10) canyons are the only Ebro margin tributaries to the Valencia Channel. 230 These canyons, also called respectively "5", "4" and "3" in Canals et al. (2000), display 231 narrower thalwegs and better-developed constructional levees than those in the Catalan 232 margin. They join the Valencia Channel at 2030, 1900 and $1775 \mathrm{~m}$ water depth 233 respectively (Fig. 3a-c). The Columbretes Grande Canyon, called "1" in Canals et al. 234 (2000), is located south of the Ebro margin and it is disconnected from the VTTS (Fig. 1). 235 This $75 \mathrm{~km}$ long canyon shows the highest sinuosity (1.40) of the studied margin and it 236 develops atop a convex relief along the continental slope and rise, ending into the deep basin approximately at $1350 \mathrm{~m}$ water depth. The Valencia Channel shows maximum incision $(370 \mathrm{~m})$ in the middle course, about 150 $\mathrm{km}$ away from the head, downstream from Foix Canyon junction (Fig. 2c and 4). In this segment the deep-sea channel achieves high sinuosity (Fig. 1) and maximum channelwall steepness (up to $\mathbf{1 8}^{\circ}$ ). The Valencia Channel thalweg shows a very gentle slope

243 (maximum: $0.6^{\circ}$ ) with an upward concave curvature along most of its length (Fig. 2b). 244 Large terraces have been identified along the Valencia main course, two along the Ebro margin-reach and six along the South and North Catalan margin reach of the Channel (named T1-T8 in Fig. 3). Sidescan sonographs obtained using the $30 \mathrm{kHz}$ TOBI system show numerous instability features in the Valencia Channel flanks near the Vinaròs junction (Fig. 5). Channel, best-fit surfaces to intercanyon margin profiles are computed. These are 
obtained by interpolating a surface from bathymetric control points on canyon and channel interfluves. The surface reveals a hypothetical smooth margin that provides a reference elevation for calculating canyon relief along the trace of the canyon thalwegs. Distance-relief plots normalized by the total relief show outstanding differences in the amount of canyon entrenchment (Fig. 6). Southern canyons (Hirta, Vinaròs and Orpesa Canyons) display lower relief than northern canyons (Blanes, Besòs and Foix canyons) and have lower courses that are mostly perched above the surrounding basin floor (negative relief) showing predominance of depositional processes along the lower course of channels in the Ebro Margin.

Most of the Ebro and Catalan canyon-channel tributaries grade smoothly into the Valencia Channel (i.e. no jump in the long profile elevation), but on closer inspection anomalies are seen at or near some junctions (Figs. 3, 5 and 7). Hirta Canyon appears to be hanging $60 \mathrm{~m}$ above the Valencia Channel, and Vinaròs Canyon shows a sharp increase in slope at a long-profile discontinuity $8 \mathrm{~km}$ upstream of its junction. We describe these features as knickpoints and discuss their morphodynamic implications in the following section.

\section{Discussion}

272

\subsection{Long-profile analysis}

274

The concordance between the Valencia Channel and most of its tributaries (Blanes, Besòs, Arenys, Foix and Orpesa, Fig. 3) suggests tandem entrenchment of the submarine drainage network. As pointed out by Mitchell (2005b), this is essentially an application of Playfair's Law for fluvial systems (Playfair, 1802; Niemann et al., 2001) to submarine channel networks. This implies that turbidity currents occur frequently enough to keep each tributary confluence at the same elevation as the Valencia Channel. This is clearly not the case for the prominent knickpoints seen on the long-profiles of Vinaròs and Hirta canyons (Fig. 3).

The knickpoint in Vinaròs Canyon (Fig. 5) indicates localized erosion across the steepened step that defines it. We assume that the disequilibrium steepening was caused by a change in the Valencia Channel's entrenchment relative to Vinaròs Canyon, since no hard variations in substrate erodibility has been documented in the area (Field and 
profile below the knickpoint is in equilibrium with the current Valencia Channel but the upstream segment defines a long-profile that is continuous with that of a relict Valencia

291 Channel thalweg. In other words, the location of the knickpoint marks the boundary between the adjusted and unadjusted reaches of the canyon-channel system, and has migrated upstream from its junction with the Valencia Channel while maintaining its steep form (Figs. 5 and 7).

We interpret Hirta Canyon's hanging terminus similarly. Yet unlike Vinaròs Canyon, Hirta Canyon's knickpoint is evidently stationary. We therefore infer that turbidity-current activity has largely shutdown in Hirta Canyon, freezing the knickpoint as a hanging valley (Figs. 3b and 7).

300

We illustrate the geometry of the long-profile adjustment using simple least-squares fits to the Ebro margin long-profiles. We choose a power-law slope-distance relation for each canyon following process-based studies on canyon form (Mitchell, 2004; Gerber et al., 2009). We first fit the concordant long-profiles of the Orpesa Canyon and the Valencia Channel (profiles 1 and 2, Fig. 7). We then fit the segments of Hirta and Vinaròs canyons that lie above the observed knickpoints and extend the fitted profiles along the course of the Valencia Channel (profiles 3 and 4, Fig. 7). We interpret the basinward projection of the Hirta and Vinaròs long-profile fits as an estimate for a relict Valencia Channel longprofile. The average depth difference between the extrapolated profiles and the modern Valencia long-profile in the present junction is $140 \mathrm{~m}$ for the Vinaròs Canyon and $60 \mathrm{~m}$ for the Hirta Canyon. Both extrapolated profiles approximate the elevation of numerous terraces observed above the modern Valencia thalweg (Figs. 3 and 7).

The long-profile fits in Fig. 7 imply that entrenchment of the Valencia Channel outpaced that occurring at the outlet of Hirta and Vinaròs canyons. The observations noted above from Hirta Canyon suggest it may no longer be active, in which case upstream flows (mainly from Orpesa Canyon) have continued sculpting the Valencia Channel as Hirta's terminus became a hanging valley. Yet the Vinaròs Canyon appears active, so the origin of its knickpoint is more controversial. In the following section we discuss factors both upstream and downstream of the Hirta and Vinaròs junctions with the Valencia Channel that may have caused their disequilibrium form. 
328 There is abundant evidence that the Ebro margin segment of the Valencia Channel has been affected by past instability on the adjacent continental slope (Canals et al., 2000; Lastras et al., 2002, 2004; Urgeles et al., 2006). Debris flows periodically disrupted canyon tributaries south of Orpesa and buried the upper reaches of the Valencia Channel. A high-resolution seismic profile that approximately follows the uppermost course of the present Valencia Channel thalweg (Fig. 8) shows acoustically transparent seismic facies (30 ms TWT maximum thickness in the considered segment) burying a paleo-surface interpreted as the ancient Valencia Channel floor. The transparent deposit belongs to the distal end of the large BIG'95 debris flow sourced from the Ebro continental slope around 11,500 cal. yr. BP (Lastras et al., 2002). Seismic profiles nearly perpendicular to the present Valencia Channel thalweg (see tracklines in Fig. 8) reveal no significant shifting of the channel position since the debris flow event and part of the buried Valencia Channel thalweg profile (Fig. 7). Like the reaches of Vinaròs and Hirta canyons above their knickpoints, this buried profile is not concordant with the current Valencia Channel profile.

Therefore, the disruption of part of the VTTS probably caused a sudden change in sedimentation style in the upper segment of the Valencia drainage network, with a significant decrease in sediment transport and incision capacity (Fig. 9). The truncation of canyons by the source area of the BIG'95 debris flow (Lastras et al., 2004) illustrates this. Therefore, the downcutting of the Valencia Channel should be dominated by turbidity currents from the canyons draining the Catalan margin, i.e. the current Valencia Channel mid-course. This could have generated the local lowering of the base level at the termini of Hirta and Vinaròs canyons, followed by knickpoint formation. It was probably strengthened by a relative increase of the size and/or frequency of turbidity currents from Orpesa Canyon. This is clear not only from its long-profile, but also its incision into the BIG'95 debris flow described above (Fig. 8).

\subsubsection{Change in spatial gradient (downstream control)}

As discussed above, knickpoints in Vinaròs and Hirta canyons and the present Valencia

360 Channel profile illustrate an "upstream" wave of erosion in the turbidite system. 361 Interestingly, these anomalies all lay upstream of the Foix Canyon junction. No remarkable discontinuities are observed downstream along the Catalan margin (Figs. 2a 
and 7). Consequently, Foix Canyon and the canyons downstream stand out as key components in the Valencia drainage network.

Foix Canyon's high-relief, smooth and low-gradient slope, and a gentle junction with the Valencia Channel suggest significant sediment bypassing to the contiguous Valencia Channel. In this view, Foix Canyon is graded from turbidity current throughput that exceeds clinoform-generating background sedimentation (Case I conditions in Gerber et al., 2009). This agrees with modern sediment transfer studies that show the canyon as a preferential conduit for sediment leaving the Catalan continental shelf to the south of Barcelona (Puig and Palanques, 1998; Puig et al., 2000).

An absolute increase of turbidity current inputs to the Valencia drainage network from Foix Canyon, but also from Arenys, Besòs and Blanes canyons, might increase transport capacity and erosion rates downstream of their junctions. Given the long-profile pattern in Fig. 7, this downstream control would seem to require the development of a strong spatial gradient in downcutting rates along the Valencia Channel middle course (Fig. 9). A decrease in direct turbidite inputs from the Ebro margin to the Valencia Channel due to burial of drainage conduits, as discussed above, would further increase the gradient in transport capacity downstream of the Catalan margin inputs. Furthermore, an absolute increase in the number of flows entering directly into the Foix Canyon during glacioeustatic lowstands, when the canyon head was close to paleo-river mouths (i.e. the paleo-Llobregat River mouth), would also increase erosion capacity along the Catalan reach of the Valencia Channel (Fig. 9). Maximum incision $(370 \mathrm{~m}$ ) of the Valencia Channel occurs after Foix Canyon junction (Fig. 2c). Cross-sections of the Valencia Channel located between canyon junctions show a clear increase in relief downstream of that junction (Fig. 4). This is also well-illustrated in seismic profiles across the Valencia Trough (Alonso et al., 1995). Most of the terraces in the Valencia Channel are observed down to the Foix junction (Figs. 3 and 7). All these observations reinforce the hypothesis that Foix Canyon drives the VTTS dynamics.

The location of the VTTS base-level has been highly variable during the Plio-Pleistocene (Palanques et al., 1994, 1995). The variation is mainly due to the internal factors described above (i.e. changes in catchment area and sediment dynamics) but also because of external ones (i.e. sediment contribution from systems outside the VTTS). Sediment is delivered to the Valencia Channel lower course from northerly sediment flows traversing the Rhône deep-sea fan and associated canyons and channels (Droz 
and Bellaiche, 1985; Palanques et al., 1995). Gulf of Lion cascading events also supply periodically large amounts of sediment to the deep-basin (Canals et al., 2006).

\subsection{Long-term time-averaged net erosion rates}

Glacio-eustatic oscillations and large sediment instability events have been identified as the likely triggers for channel migration and long-profile anomalies in the VTTS (Fig. 9). The estimated age for the last large landslide affecting the upper catchment of the VTTS is 11,500 cal. yr. BP (Lastras et al., 2002). The last lowstand episode (110-120 m below present sea level) occurred during Marine Isotope Stage (MIS) 2, about 18,000 yr BP (Waelbroeck et al., 2002).

The total incision of the Valencia Channel with respect to the projected power fits to the Vinaròs $(140 \mathrm{~m})$ and Hirta $(60 \mathrm{~m})$ canyons (Fig. 7), combined with timing for drainage network disturbance, provides estimates for time-averaged net erosion rates. If incision followed the last major landslide on the Ebro margin then the downcutting rate is $12.1 \mathrm{~m}$ $\mathrm{kyr}^{-1}$ around Vinaròs junction and $5.2 \mathrm{~m} \mathrm{kyr}^{-1}$ around Hirta junction. If incision was triggered during the last glacio-eustatic lowstand then the downcutting rates are 7.7 and $3.3 \mathrm{~m} \mathrm{kyr}^{-1}$, respectively. These values should be regarded as maximum time-averaged net erosion rates because we are using the most recent events capable of triggering the channel adjustment. If the VTTS adjustment commenced during an earlier lowstand (e.g. during the MIS 4 lowstand, see Waelbroeck et al., 2002) or after an earlier landslide (e.g. Ebro margin buried landslides identified in seismic reflection profiles, see Lastras et al., 2007) we would obviously calculate slower denudation rates.

The given range of values should not be considered as pure erosion rates but rather net erosion rates. In other words, long-term time-averaging integrates many episodes of erosion and deposition. Hence, they should be regarded as maximum relief generation rates.

Turbidity currents erode the seabed through the shear stress they exert as they move over it (Pratson et al., 2000). Unfortunately, measuring turbidity currents in situ is difficult, so experimental and numerical studies are the only source of erosion rate estimates (Garcia and Parker, 1989; Kneller et al., 1999, Pratson et al., 2000, 2001). Consequently, the uncertainties concerning the scaling of laboratory-derived relationships make comparisons with natural turbid surges essentially qualitative. However, numerical 
437 models consistently show that the erosive capacity of a turbidity current tends to increase

438 with its size or the slope length (Pratson et al., 2000; Mitchell, 2004). This is because 439 entrainment of sediment into the current increases its momentum, which in turn increases 440 the current's transport capacity and thus its ability to erode the bed. For reference, 441 numerical simulations of turbidity currents by Pratson et al. (2000) suggest erosion rates 442 of a few meters per event. Using a 3D slope stability model applied to a submarine 443 canyon on the nearby Gulf of Lion, Sultan et al. (2007) suggested that slope instabilities 444 and reshaping of canyon walls can be triggered after only $5 \mathrm{~m}$ of axial incision.

446 Thus, it is reasonable to expect high long-term erosion rates caused by repeated turbidity 447 currents in the Valencia Channel in light of the observed size of the drainage network, the 448 outstanding relief and width of the Valencia Channel in its middle-course (Fig. 2), the 449 development of extensive levees along the lower course (Alonso et al., 1995) and the 450 extension of the Valencia Fan (Palanques et al., 1994). Furthermore, it is also remarkable 451 the morphologic inconsistency between the buried long-profile of the ancient Valencia 452 Channel upper course (Fig. 7) and the present profile, which again points to drastic 453 channel adjustment after the occurrence of the BIG'95 debris flow at the Ebro margin. 454 The terminal Valencia Lobe (Droz et al., 2006), which extends more than $150 \mathrm{~km}$ downdip 455 on the Algero-Balearic abyssal plain east of the Minorca Island, also records the activity 456 of the Valencia Channel in fresh bedforms and erosional features as well as layers 457 containing pteropod shells of Holocene age (Morris et al., 1998). At this stage the extent 458 to which these fresh bedforms and erosional features are attributable to repeated turbidity 459 currents and not the frequent highstand cascades of dense shelf water is unknown 460 (Canals et al., 2006; Gaudin et al., 2006). Direct evidence of long-term erosion in the 461 Valencia Channel was observed during Deep Sea Drilling Project Leg 13 site 122 (Ryan 462 et al., 1973), located very close to the middle-course of the current thalweg (Figs. 1 and 463 4). Sediments recovered from the borehole showed a late-middle Quaternary coarse464 grained top unit directly overlying Upper Pliocene sediments (Ryan et al., 1973). The 465 time-gap estimated for the unconformity is at least one million years. 


\section{Conclusions}

468

The analysis of along-thalweg depth profiles (i.e. long-profiles) in turbidite systems yields information about the sedimentary history of a submarine basin. In the present study we examine long-profiles to address the long-term evolution of the Valencia Trough turbidite system (VTTS).

473

The VTTS is unique because it drains sediment from different margin morpho-types that share a common final conduit, the Valencia Channel. This margin-to-margin interconnection allows the propagation of local effects through the whole system. The integrated analysis of turbidite channel long-profiles shows evidence for transient incision in the VTTS in the form of a knickpoint in Vinaròs Canyon and a hanging tributary in Hirta Canyon. Based on the location and form of these morphologies we identify two main triggering mechanisms that may have caused their disequilibrium form: (1) a change in sedimentation style forced by a large debris flow at $11,500 \mathrm{yr}$ BP that disrupted the upper reaches of the VTTS, and (2) a change in downcutting rates along the Valencia Channel middle course due to shifting sediment input during glacio-eustatic lowstands. From our morphometric observations, we conclude that the South Catalan canyons, especially Foix Canyon, played a key role in the drainage dynamics of the VTTS.

Long-term time-averaged Valencia Channel incision rates have been estimated based on the two incision triggering mechanisms inferred above. From assumed dates for the onset of incision in these two scenarios, incision rates around the Vinaròs junction are from 7.7 to $12.1 \mathrm{~m} \mathrm{kyr}^{-1}$, while near Hirta junction are from 3.3 to $5.2 \mathrm{~m} \mathrm{kyr}^{-1}$. These values should be taken as rough estimates for maximum relief generation rates in the submarine channel.

493

494 In this paper we have shown how new detailed bathymetry across an entire basin 495 provides clues to the evolution of submarine drainage networks shaped primarily by the 496 action of turbidity currents. Like studies of landscape evolution from DEMs, our work 497 makes inferences about seascape evolution from high-quality bathymetry. Even in the 498 absence of extensive subsurface data, much can be learned about recent basin evolution from detailed observations of the modern seascape. 
504 This research was supported by the HERMIONE project, EC contract 226354-

505 HERMIONE, funded by the European Commission's Seventh Framework Programme,

506 and the HERMES Project, EC contract GOCE-CT-2005-511234, funded by the European

507 Commission's Sixth Framework Programme under the priority "Sustainable Development,

508 Global Change and Ecosystems". It has also benefited from inputs by the PROMETEO

509 (CTM2007-66316-C02-01/MAR), EDINSED3D (CTM2007-64880/MAR), and the

510 GRACCIE CONSOLIDER (CSD2007-00067) projects, both funded by the Spanish RTD

511 Programme. GRC Geociències Marines is supported by Generalitat de Catalunya "Grups

512 de Recerca Consolidats" grant 2009 SGR 1305. The paper was substantially improved by

513 constructive reviews by P.P. Cunha and editor T. Oguchi.

514 
Adeogba, A.A., McHargue, T.R., Graham, S.A., 2005. Transient fan architecture and depositional controls from near-surface 3-D seismic data, Niger Delta continental slope. Am. Assoc. Pet. Geol. Bull. 89, 627-643.

520

Alonso, B., Field, M.E., Gardner, J.V., Maldonado, A., 1990. Sedimentary evolution of the Pliocene Ebro margin, northeastern Spain. Mar. Geol. 95, 313-331.

523

524

Alonso, B., Canals, M., Got, H., Maldonado, A., 1991. Seavalleys and related depositional systems in the Catalan Sea (northwestern Mediterranean Sea). Am. Assoc. Pet. Geol. Bull. 75, 1195-1214.

Alonso, B., Canals, M., Palanques, A., Rehault, J.P., 1995. A deep-sea channel in the northwestern Mediterranean Sea: Morphology and seismic structure of the Valencia Channel and its surroundings. Mar. Geophys. Res. 17, 469-484.

530

Amblas, D., Canals, M., Lastras, G., Berné, S., Loubrieu, B., 2004. Imaging the seascapes of the Mediterranean. Oceanography 17(4), 144-155.

533

Amblas, D., Canals, M., Urgeles, R., Lastras, G., Hughes-Clarke, J.E., 2006. Morphogenetic mesoscale analysis of the northeastern Iberian margin, NW Mediterranean basin. Mar. Geol. 234, 3-20.

Berné, S., Loubrieu, B., CALMAR Ship-board Party, 1999. Canyons et processus sédimentaires récents sur la Marge Occidentale du Golfe du Lion. Premiers Résultats de la Campagne Calmar. C.R. Acad. Sci. 328, 471-477.

541

542 Bouma, A., Normark, W. R., Barnes, N. E., 1986. Submarine Fans and Related Turbidite Systems. Springer Verlag, New York.

544

545 Boyd, R., Ruming, K., Goodwin, I., Sandstrom, M., Schröder-Adams, C., 2008. Highstand transport 546 for coastal sand to the deep ocean: a case study from Fraser Island, southeast Australia. Geology $547 \quad 36,15-18$.

548

549 Canals, M., Alonso, B., Baraza, J., Ercilla, G., Calafat, A.M., Masson, D.G., Farran, M., Sorribas, 550 J., Estrada, F., Cavaller, M., Prieto, M.J., Rodríguez, J.P., Maillard, N., 1995. Estudio oceanográfico multidisciplinar del Mar Catalano-Balear; Informe de la Campaña BIG 95. Cruise report (in Spanish, with English Abstr.). Universitat de Barcelona, Barcelona, Spain, 94 pp. 
Canals, M., Casamor, J.L., Urgeles, R., Lastras, G., Calafat, A.M., De Batist, M., Masson, D., Berné, S., Alonso, B., Hughes-Clarke, J.E., 2000. The Ebro continental margin, Western Mediterranean Sea: Interplay between canyon-channel systems and mass wasting processes. In: Nelson, C.H., Weimer, P. (Eds.), Deep-water Reservoirs of the World: GCSSEPM Foundation 20th Annual Research Conference, Houston, Texas, pp.152-174 (CD edition).

Canals, M., Puig, P., Durrieu de Madron, X., Heussner, S., Palanques, A., Fabres, J., 2006. Flushing submarine canyons. Nature 444, 354-357.

Cattaneo, A., Trincardi, F., Langone, L., Asioli, A., Puig, P., 2004. Clinoform generation on Mediterranean margins. Oceanography 17(4), 105-117.

Cita, M.B., Ryan, W.B.F., Kidd, R.B., 1978. Sedimentation rates in Neogene deep-sea sediments from the Mediterranean and geodynamic implications of their change. In: Hsü, K.J., Montadert, L., and others (Eds.). Initial Reports of the Deep Sea Drilling Project 42, Part I, Government Printing Office, Washington D.C., pp. 991-1002.

Cook, K.L., Whipple, K.X., Heimsath, A.M., Hanks, T.C., 2009. Rapid incision of the Colorado River in Glen Canyon - insights from channel profiles, local incision rates, and modeling of lithologic controls. Earth Surf. Process. Landforms 34, 994-1010.

Covault, J.A., Romans, B.W., 2009. Growth patterns of deep-sea fans revisited: Turbidite-system morphology in confined basins, examples from the California Borderland. Mar. Geol. 265, 51-66.

Crosby, B.T., Whipple, K.X., 2006. Knickpoint initiation and distribution within fluvial networks: 236 waterfalls in the Waipaoa River, North Island, New Zealand. Geomorphology 82, 16.38.

Dana, J.D., 1863. Manual of Geology: Treating of the Principles of the Science with Special Reference to American Geological History, for the Use of Colleges, Academies, and Schools of Science. Theodore Bliss \& Co., Philadelphia, 798 pp.

Droz, L., Bellaiche, G., 1985. Rhône Deep-sea Fan: morphostructure and growth pattern. Am. Assoc. Pet. Geol. Bull. 69, 460-479.

Droz, L., dos Reis, A.T., Rabineau, M., Berné, S., Bellaiche, G., 2006. Quaternary turbidite systems on the northern margins of the Balearic Basin (Western Mediterranean): a synthesis. Geo-Mar. Lett. 26, 347-359.

Field, M.E., Gardner, J.V., 1990. Pliocene-Pleistocene growth of the Rio Ebro margin, northeast Spain: a prograding-slope model. Geol. Soc. Am. Bull. 102, 721-733. 
595 Garcia, M., Parker, G., 1989. Experiments on hydraulic jumps in turbidity currents near a canyon-

596 fan transition. Science 245(4916), 393-396.

598 Gaudin, M., Berné, S., Jouanneau, J.M., Palanques, A., Puig, P., Mulder, T., Cirac, P., Rabineau, 599 M., Imbert, P., 2006. Massive sand beds attributed to deposition by dense water cascades in the 600 Bourcart canyon head, Gulf of Lions (northwestern Mediterranean Sea). Mar. Geol. 234, 111-128.

601

602 Gerber, T.P., Amblas, D., Wolinsky, M.A., Pratson, L.F., Canals, M., 2009. A model for the long603 profile shape of submarine canyons. J. Geophys. Res. 114, F03002.

604

605

Howard, A.D., Dietrich, W.E., Seidl, M.A., 1994. Modeling fluvial erosion on regional to continental

606 scales. J. Geophys. Res. 99, 13971-13986.

607

608

Kertznus, V., Kneller, B., 2009. Clinoform quantification for assessing the effects of external forcing

609 on continental margin development. Basin Res. 21, 738-758.

610

611

Kneller, B. C., Bennett, S.J., McCaffrey, W.D., 1999. Velocity structure, turbulence and fluid stresses in experimental gravity currents. J. Geophys. Res. 104(C3), 5381-5391.

613

614 Kneller, B., 2003. The influence of flow parameters on turbidite slope channel architecture. Mar. 615 Petrol. Geol. 20, 901-910.

616

617 Lastras, G., Canals, M., Hughes-Clarke, J.E., Moreno, A., De Batist, M., Masson, D.G., Cochonat, 618 P., 2002. Seafloor imagery from the BIG'95 debris flow, western Mediterranean. Geology 30, 871619874.

620

621 Lastras, G., Canals, M., Urgeles, R., De Batist, M., Calafat, A.M., Casamor, J.L., 2004. 622 Characterisation of the recent BIG'95 debris flow deposit on the Ebro margin, Western 623 Mediterranean Sea, after a variety of seismic reflection data. Mar. Geol. 213, 235-255.

624

625 Lastras, G., Canals, M., Amblas, D., Frigola, J., Urgeles, R., Calafat, A.M., Acosta, J., 2007. Slope 626 instability along the northeastern Iberian and Balearic continental margins. Geol. Acta 5, 35-47.

627

628 Lastras, G., Canals, M., Amblas, D., Lavoie, C., Church, I., De Mol, B., Duran, R., Calafat, A.M., 629 Hughes-Clarke, J.E., Smith, C., Heussner, S., Euroleón cruise shipboard party, 2011. 630 Geomorphology of Blanes and La Fonera canyon heads, western Mediterranean Sea. Mar. Geol. 631 doi:10.1016/j.margeo.2010.11.005. 
Maillard, A., Mauffret, A., 1999. Crustal structure and riftogenesis of the Valencia Trough (northwestern Mediterranean Sea). Basin Res. 11, 357-379.

635

Maillard, A., Gorini, C., Mauffret, A., Sage, F., Lofi, J., Gaullier, V., 2006. Offshore evidence of polyphase erosion in the Valencia Basin (Northwestern Mediterranean): Scenario for the Messinian Salinity Crisis. Sediment. Geol. 188-189, 69-91.

639

Mitchell, N.C., 2005a. Interpreting long-profiles of canyons in the USA Atlantic continental slope.

645

Mitchell, N.C., 2005b. Erosion of canyons in continental slopes. In: Hodgson, D.M., Flint, S.S.

(Eds.), Submarine Slope Systems; Processes and Products. Geological Society Special Publications 244, London, pp. 131-140.

649

650

Mitchell, N.C., 2006. Morphologies of knickpoints in submarine canyons. GSA Bull. 118, 589-605.

651

Mitchum, R.M.Jr., Vail, P.R., Sangree, J.B., 1977. Seismic stratigraphy and global changes of sea levels, part 6: stratigraphic interpretation of seismic reflection patterns in depositional sequences: in Payton, C.E. (Ed.), Seismic Stratigraphy Applications to Hydrocarbon Exploration, AAPG Memoir 26, pp. 117-133.

659

Morris, S.A., Kenyon, N.H., Limonov, A.F., Alexander, J., 1998. Downstream changes of largescale bedforms in turbidites around the Valencia channel mouth, north-west Mediterranean: implications for palaeoflow reconstruction. Sedimentology 45, 365-377. Playfair's Law and its use in testing long-term stream erosion models. Earth Surf. Process. Landforms 26, 1317-1332.

668 Nittrouer, C.A., Kuehl, S.A., DeMaster, D.J., Kowsmann, R.O., 1986. The deltaic nature of Amazon shelf sedimentation. GSA Bull. 97, 444-458. 
674 Olley, J.M., Pietsch, T., Roberts, R.G., 2004. Optical dating of Holocene sediment from a variety of

675 geomorphic settings using single grains of quartz. Geomorphology 60, 337-358.

676

677 Palanques, A., Maldonado, A., 1985. Sedimentology and evolution of the Valencia Valley and Fan

678 (Northwestern Mediterranean). Acta Geol. Hisp. 20, 1-19.

679

680 Palanques, A., Alonso, B., Farrán, M., 1994. Progradation and retreat of the Valencia fanlobes

681 controlled by sea level changes during the Plio-Pleistocene (Northwestern Mediterranean). Mar.

682 Geol. 117, 195-205.

683

684 Palanques, A., Kenyon, N.H., Alonso, B., Limonov, A., 1995. Erosional and Depositional Patterns 685 in the Valencia channel Mouth: An example of a Modern Channel-Lobe Transition Zone. Mar. 686 Geophys. Res. 17, 503-517.

687

688 Petter, A.L., Kim, W., Muto, T., Steel, R.J., 2011. Comment on 'Clinoform quantification for 689 assessing the effects of external forcing on continental margin development'. Basin Res. 23, 118690121.

691

692 Pirmez, C., Beaubouef, R.T. Friedmann, S.J., Mohrig, D.C., 2000. Equilibrium profile and 693 baselevel in submarine channels: examples from Late Pleistocene systems and implications for 694 the architecture of deep water reservoirs. In: Weimar, P., Slatt, R.M., Coleman, J., Rosen, N.C., 695 Nelson, H., Bouma, A.H., Styzen, M.J., Lawrence, D.T. (Eds.), Deep-water Reservoirs of the

696 World. GCSSEPM Foundation 20th Annual Research Conference, pp. 782-805.

697

698 Pirmez, C., Imran, J., 2003. Reconstruction of turbidity currents in Amazon Channel. Mar. Petrol. 699 Geol. 20, 823-849.

700

701 Playfair, J., 1802. Illustrations of the Huttonian Theory of the Earth. Cadell and Davies, London, 702 and Greech, Edinburgh.

703

704 Pratson, L.F., Imran, J., Parker, G., Syvitski, J.P.M., Hutton, E., 2000. Debris Flows vs. Turbidity 705 Currents: a Modeling Comparison of Their Dynamics and Deposits. In: Bouma, A.H., Stone, C.G. 706 (Eds.), Fine-grained Turbidite Systems. Am. Assoc. Pet. Geol. Memoir 72/SEPM Special 707 Publication 68, pp. 57-72.

708

709 Pratson, L.F., Imran, J., Hutton, E.W.H., Parker, G., Syvitski, J.P.M., 2001. BANG1D: a one710 dimensional, Lagrangian model of subaqueous turbid surges. Comput. Geosci. 27(6), 701-716. 711 doi:10.1016/S0098-3004(00)00123-0. 
Pratson, L.F., Nittrouer, C.A., Wiberg, P.L., Steckler, M.S., Swenson, J.B., Cacchione, D.A.,

714 Karson, J.A., Murray, A.B., Wolinsky, M.A., Gerber, T.P., Mullenbach, B.L., Spinelli, G.A.,

715 Fulthorpe, C.S., O'Grady, D.B., Parker, G., Driscoll, N.W., Burger, R.L., Paola, C., Orange, D.L.,

716 Field, M.E., Friedrichs, C.T., Fedele, J.J., 2009. Seascape evolution on clastic continental shelves

717 and slopes. In: Nitrouer, C.A., Austin, J.A., Field, M.E., Kravitz, J.H., Syvitski, J.P.M., Wiberg, P.L.,

718 (Eds.), Continental-Margin Sedimentation: From Sediment Transport to Sequence Stratigraphy.

719 IAP Special Publication 37, Blackwell Publishing, Oxford, pp. 339-380.

720

721 Puig, P., Palanques, A., 1998. Nepheloid structure and hydrographic control on the Barcelona

722 continental margin, NW Mediterranean. Mar. Geol. 149, 39-54.

723

724

Puig, P., Palanques, A., Guillen, J., Garcia-Ladona, E., 2000. Deep slope currents and suspended

725 particle fluxes in and around the Foix submarine canyon (NW Mediterranean). Deep-Sea Res. 47, 343-366.

727

728

Rabineau, M., Berne, S., Aslanian, D., Olivet, J.L., Joseph, P., Guillocheau, F., 2005. Sedimentary

729 sequences in the Gulf of Lion: A record of 100,000 years climatic cycles. Mar. Petrol. Geol. 22,

730 775-804.

731

732

Roca, E., Sans, M., Cabrera, L., Marzo, M., 1999. Oligocene to Middle Miocene evolution of the central Catalan margin (northwestern Mediterranean). Tectonophysics 315, 209-233.

734

735

Ryan, W.B.F, Hsü, K.J., Cita, M.B., Dumitrica, P., Lort, J., Maync, W., Nesteroff, W.D., Pautot, G., Stradner, H., Wezel, F.C., 1973. Valencia Trough, site 122. DSDP Leg 13 site 122 Report, 91-109.

Sultan, N., M. Gaudin, S. Berne, M. Canals, R. Urgeles, Lafuerza, S., 2007. Analysis of slope failures in submarine canyon heads: an example from the Gulf of Lions. J. Geophys. Res. 112, F01009. doi:10.1029/2005fj000408.

Shepard, F.P., 1981. Submarine canyons; multiple causes and long-time persistence. Am. Assoc. Pet. Geol. Bull. 65, 1062-1077.

Urgeles, R., Leynaud, D., Lastras, G., Canals, M., Mienert, J., 2006. Back-analysis and failure mechanisms of a large submarine slide on the Ebro continental slope, NW Mediterranean. Mar. Geol. 226, 185-206.

Urgeles, R., Camerlenghi, A., Garcia-Castellanos, D., De Mol, B., Garcés, M., Vergés, J., Haslam,

750 I., Hardman, M., 2010. New constraints on the Messinian sealevel drawdown from 3D seismic data 751 of the Ebro Margin, western Mediterranean. Basin Res. doi:10.1111/j.1365-2117.2010.00477.x. 
753 Waelbroeck, C., Labeyrie, L., Michel, E., Duplessy, J.C., McManus, J.F., Lambeck, K., Balbon, E., 754 Labracherie, M., 2002. Sea-level and deep water temperature changes derived from benthic 755 foraminifera isotopic records. Quaternary Sci. Rev. 21, 295-305.

756

757 Whipple, K.X., Tucker, G.E., 2002. Implications of sediment-flux-dependent river incision models 758 for landscape evolution. J. Geophys. Res. 107(B2), 2039. doi:10.1029/2000JB000044. 
Fig. 1. DTM of the study area. Illumination is from the NE. Elevation data are a combination of different multibeam data sets and global digital databases. The white dashed lines follow the axis of the main Valencia drainage network. BIC, Blanes Canyon; AC, Arenys Canyon; BeC, Besòs Canyon; FC, Foix Canyon; ViC, Vinaròs Canyon; HiC, Hirta Canyon; OrC, Orpesa Canyon; CGC, Columbretes Grande Canyon; RDSF, Rhône Deep-Sea Fan; DPCSB, Deep Pyrenean Canyons Sedimentary Body; WDF, Western Debris Flow; BDF, BIG'95 Debris Flow. White capital letters (A-F) near canyon junctions with the Valencia Channel show the location of the bathymetric zooms displayed in Fig. 3. Black dotted boxes show location of Figs. 4, 5 and 8.

Fig. 2. Elevation-distance plots for the Valencia Trough turbidite systems. a) Longitudinal profiles of the main submarine valleys feeding the Valencia Channel from the southernmost modern tributary (Orpesa) to the Valencia Fan (distal end of plot) extracted from swath bathymetry (50 m grid resolution). Gray dotted curve is the smoothed bathymetric profile of the Valencia Channel margin parallel to its thalweg. Gray dotted box shows limits of Fig. 7. Vertical dashed lines (A-F) mark junctions of canyons with the Valencia Channel (see Fig. 3). b) Valencia Channel long-profile plotted with its elevation power-law fit (dotted curve) and the gradient of that fit (gray curve). c) Valencia Channel relief profile measured along the northern margin of the channel, and channel width measurements taken every $10 \mathrm{~km}$ (gray curve).

Fig. 3. 3D perspective view of canyon junctions $(A-F)$ with the Valencia Channel (at $4 x$ vertical exaggeration). Key features are labeled, as well as the location (in A) of the seismic line shown in Fig. 8. Terraces in the Valencia Channel are also indicated (T1T8).

Fig. 4. Bathymetric cross-sections of the Valencia Channel between canyon junctions. See Fig. 1 for location. ValCh, Valencia Channel; BIC, Blanes Canyon; AC, Arenys Canyon; BeC, Besòs Canyon; FC, Foix Canyon; ViC, Vinaròs Canyon; HiC, Hirta Canyon; OrC, Orpesa Canyon.

Fig. 5. Vinaròs canyon junction with the Valencia Channel. See Fig. 1 for location. a and b) $30 \mathrm{kHz}$ TOBI side-scan sonographs draped on multibeam bathymetry data. c) Main geomorphic features including the Vinaròs Knickpoint and the Valencia Channel terrace 
798 Fig. 6. Distance-relief plots normalized by the total relief (from canyon head to the 799 junction with the Valencia Channel) for submarine canyons draining into the Valencia 800 Channel. Local relief is computed from a best-fit surface to inter-canyon margin profiles.

801 The plots highlight differences in the amount of canyon entrenchment.

802

803 Fig. 7. Zoom of the upper and middle course of the Valencia drainage network (see Fig. $8042 a$ for location) showing interpreted features of canyon-channel long-profiles. For Hirta 805 and Vinaròs canyons, dashed lines show power-law fits to profiles above knickpoints that 806 are projected below the knickpoints and down the Valencia axis. Also shown is a power807 law fit to the Orpesa and Valencia combined long-profile. Black dotted line shows the 808 location of the buried (by the BIG'95 debris flow) Valencia Channel profile upper course 809 measured from high-resolution seismic reflection profiles nearly perpendicular to the 810 present Valencia Channel thalweg (see seismic survey tracklines in Fig. 8). Terraces 811 (T1-T8) observed along the Valencia Channel are also indicated.

812

813 Fig. 8. Very high resolution seismic reflection profile showing the distal deposit of the 814 BIG'95 debris flow covering a surface (dotted line) interpreted as a former upper thalweg 815 of the Valencia Channel. See Fig. 1 for location. Red line in the location box shows the 816 position of the seismic profile, while the black dotted lines show the rest of the seismic 817 survey navigation in the selected zone.

818

819 Fig. 9. Cartoon illustrating the conceptual model for transient profile adjustment triggered 820 by upstream (a) and downstream (b) controls. In both cases, the relative flow throughput 821 (i.e. flow-event frequency) at different parts of the Valencia Channel is represented. In (a), 822 the trigger mechanism is a decrease in flow throughput (time 2) along the Ebro reach of 823 the Valencia Channel following the disruption and burial of the upper reaches of the VTTS 824 by a submarine debris flow. In (b), the profile is adjusted by increased flow throughput 825 (time 2) during sealevel lowstands along the South Catalan Margin (SCM) reach of the 826 Valencia Channel, when canyon heads are close to river mouths. The vertical thickness 827 of the flow throughput wedges is proportional to relative flow-event frequency. 


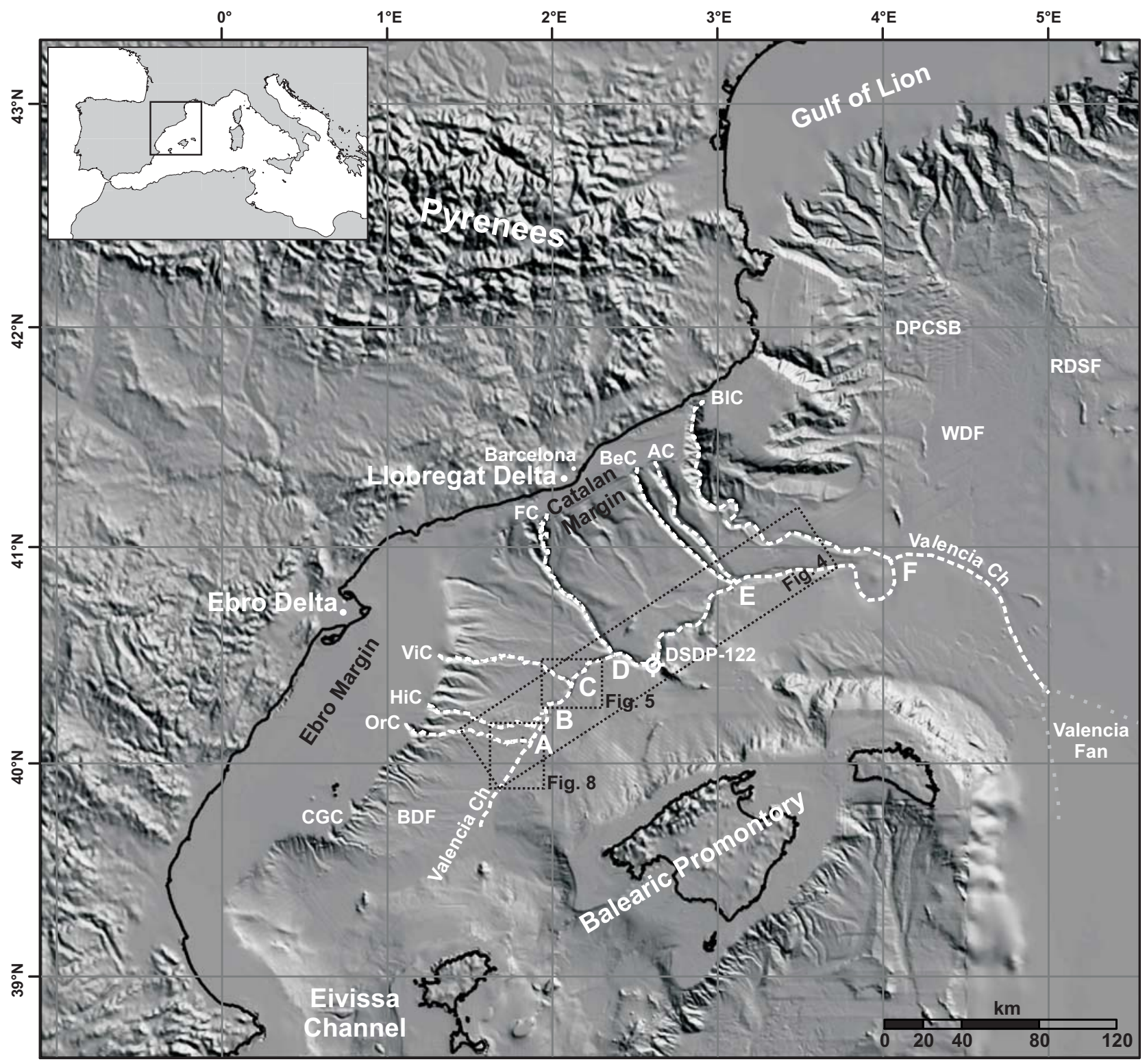

Fig.1 


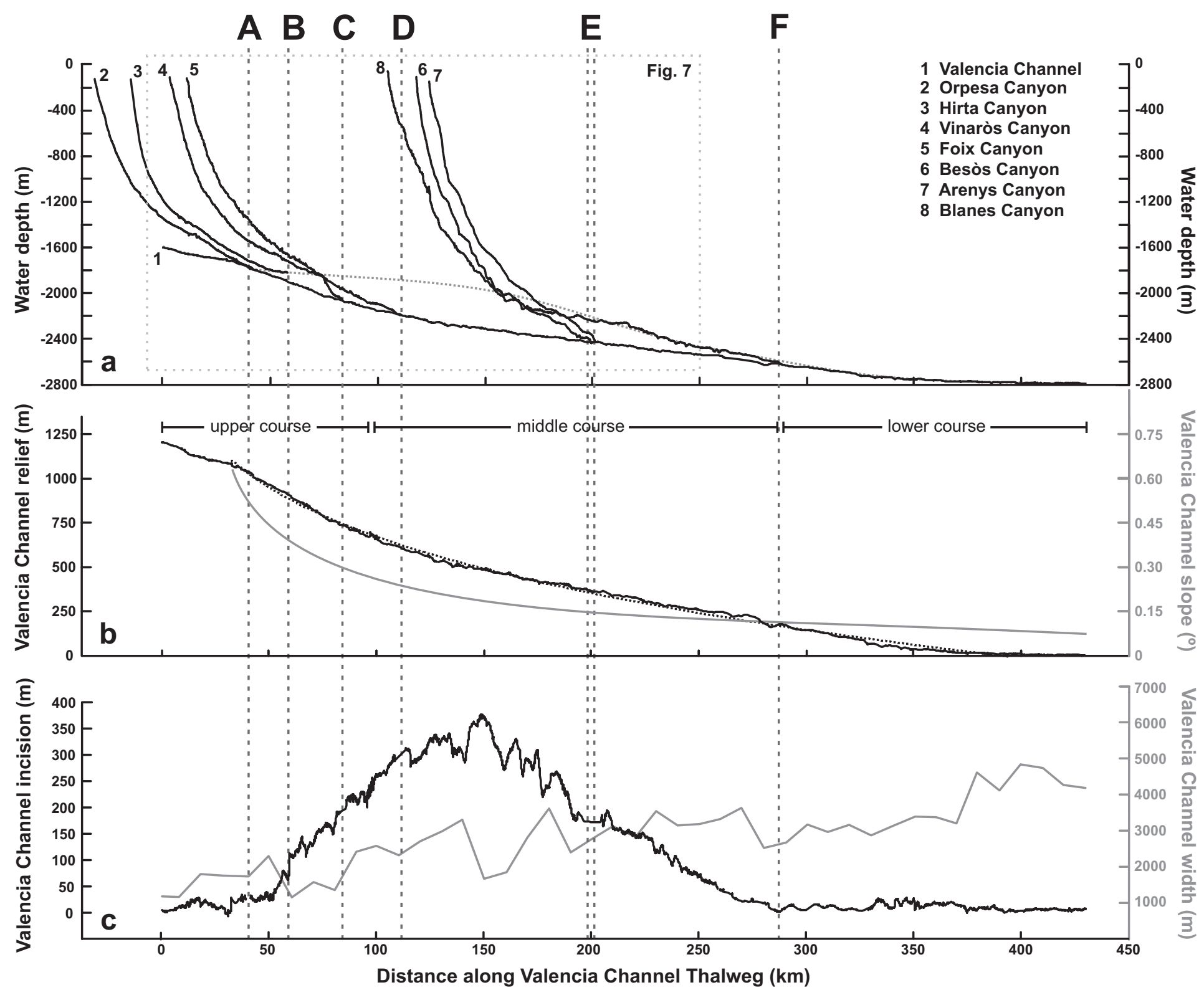

Fig.2 

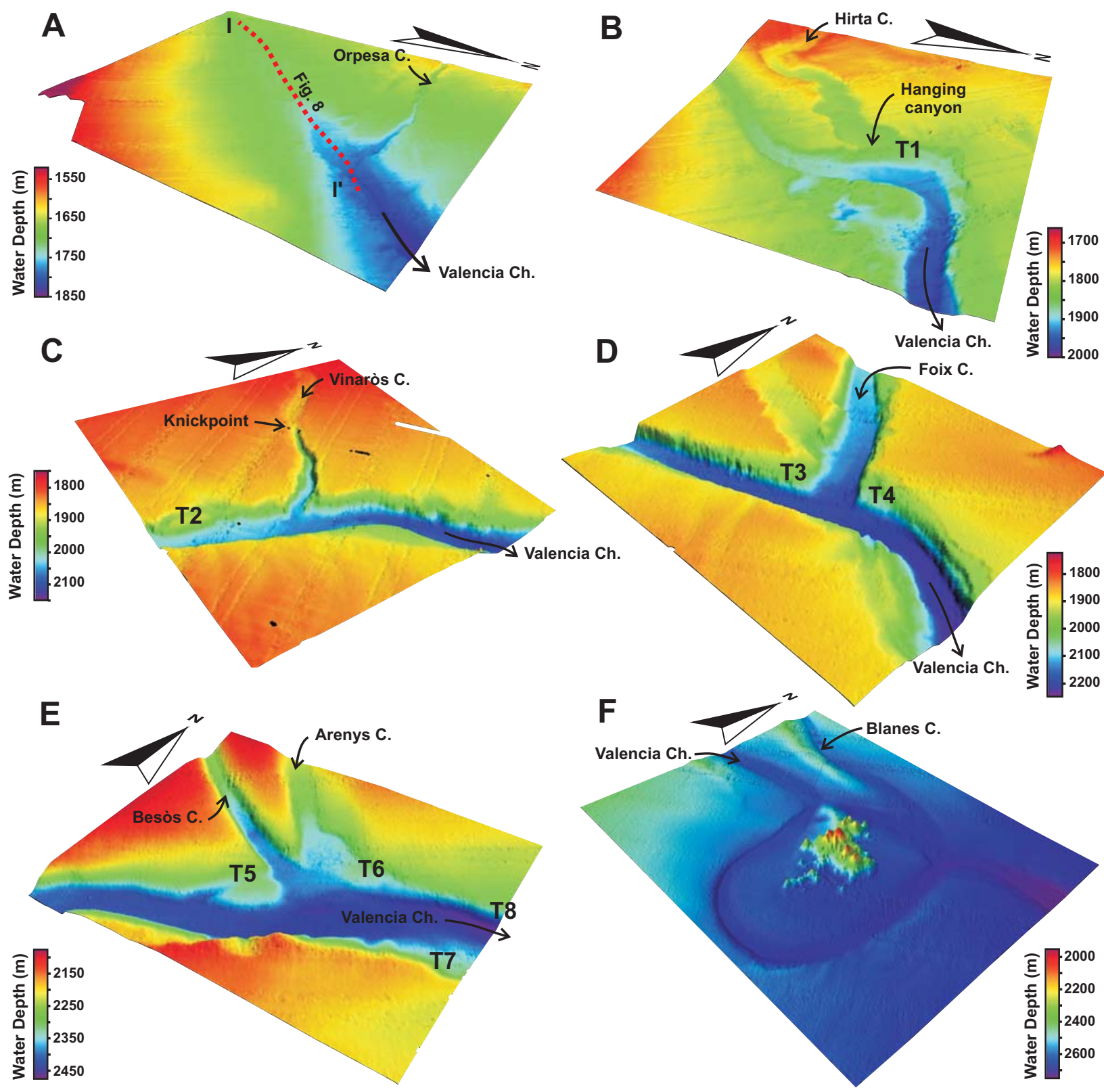

Fig.3 

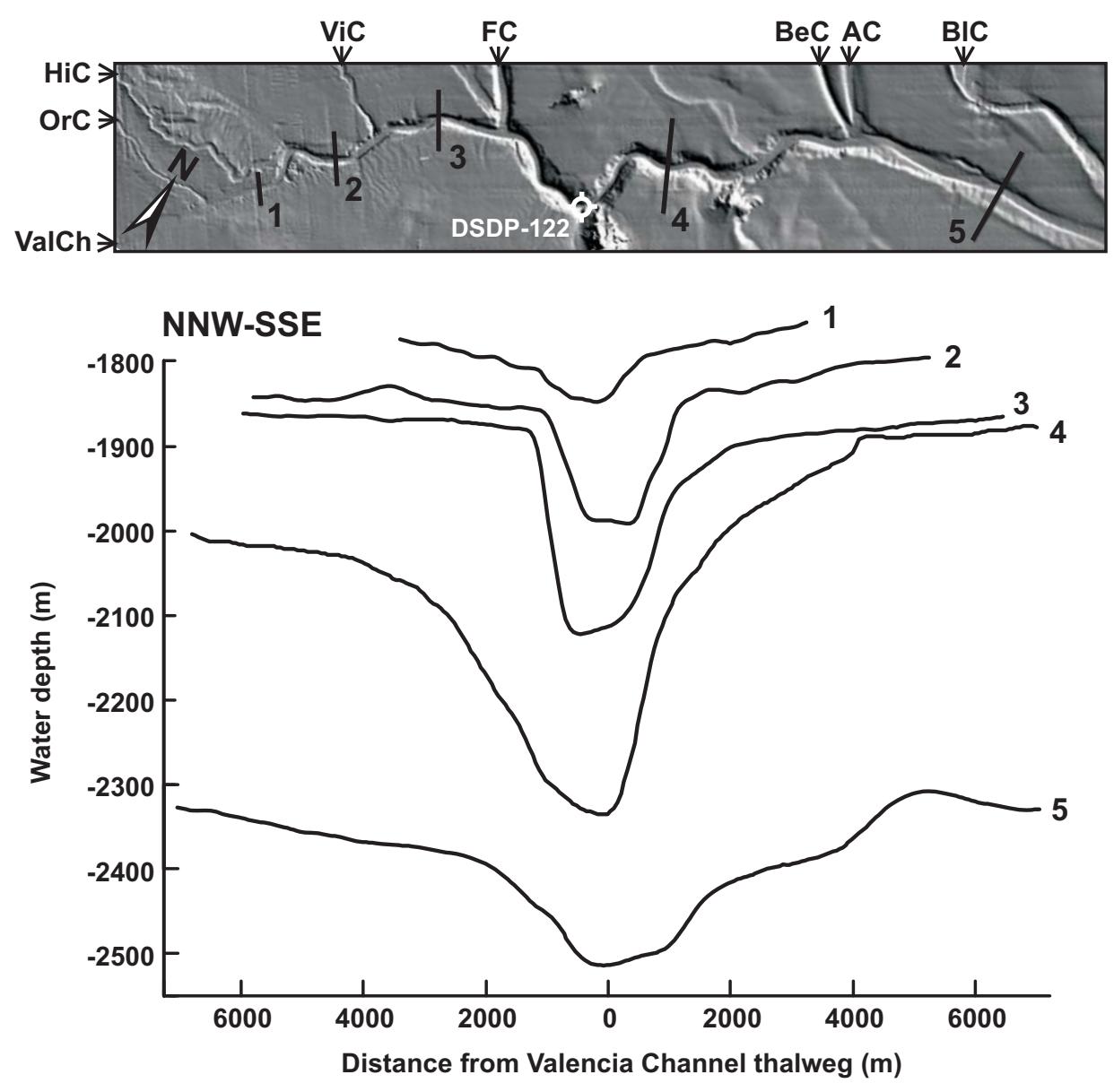

Fig.4 

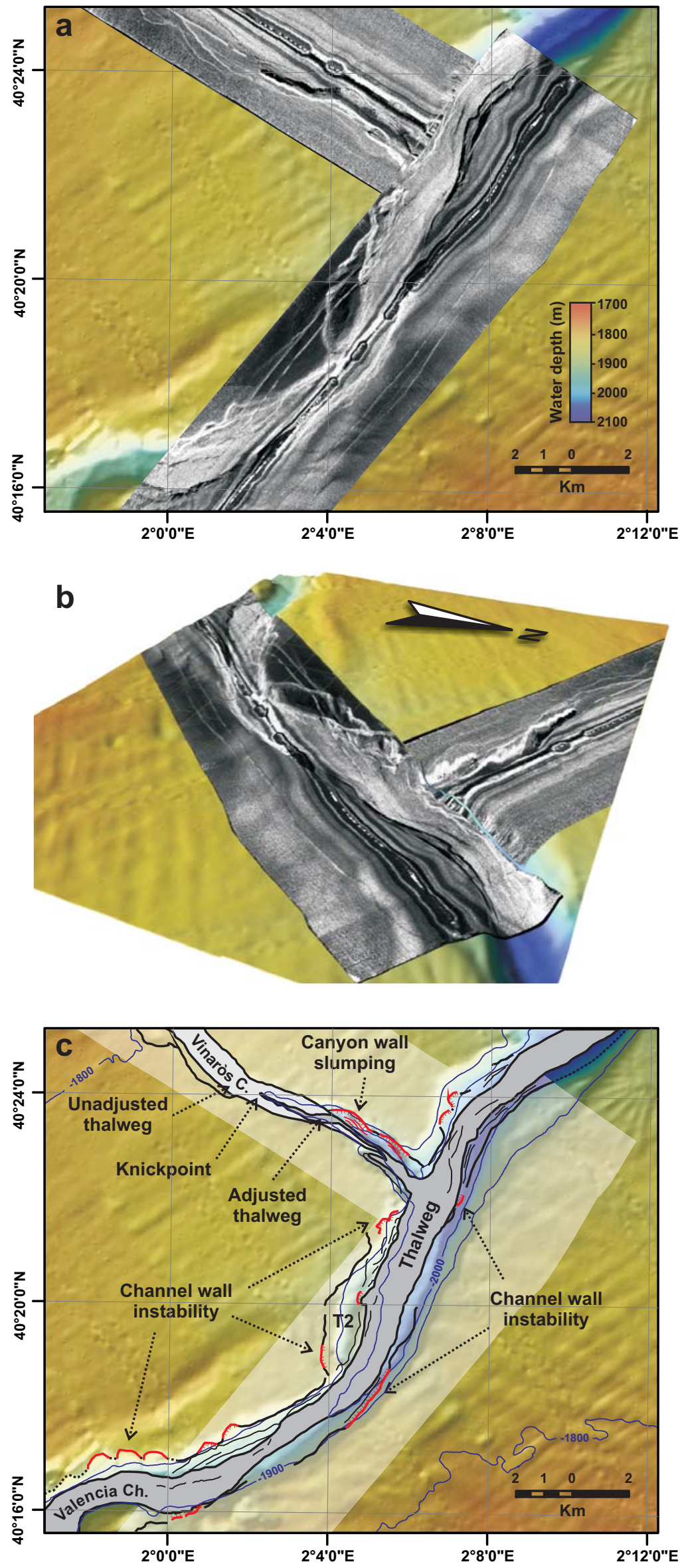

Fig.5 


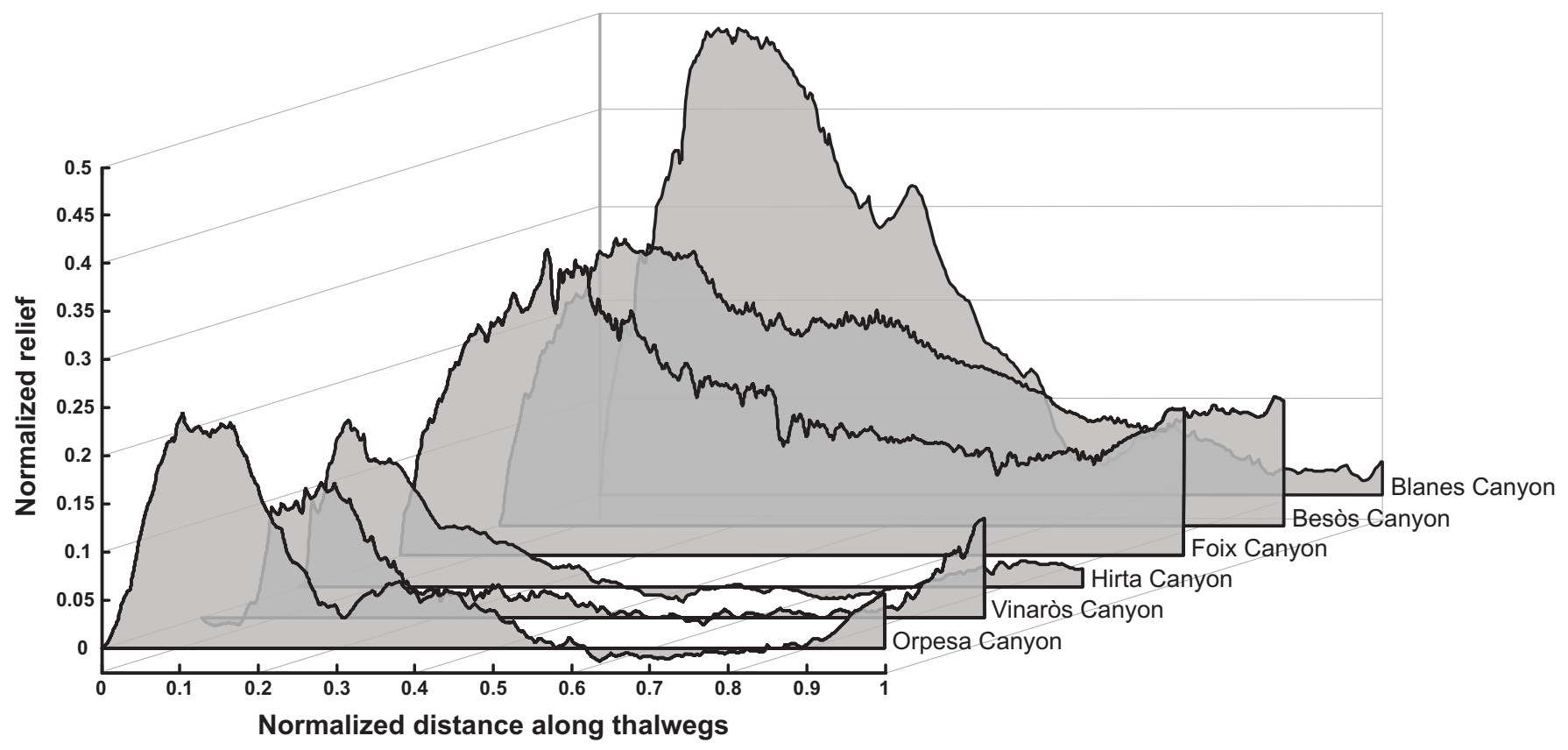

Fig. 6 


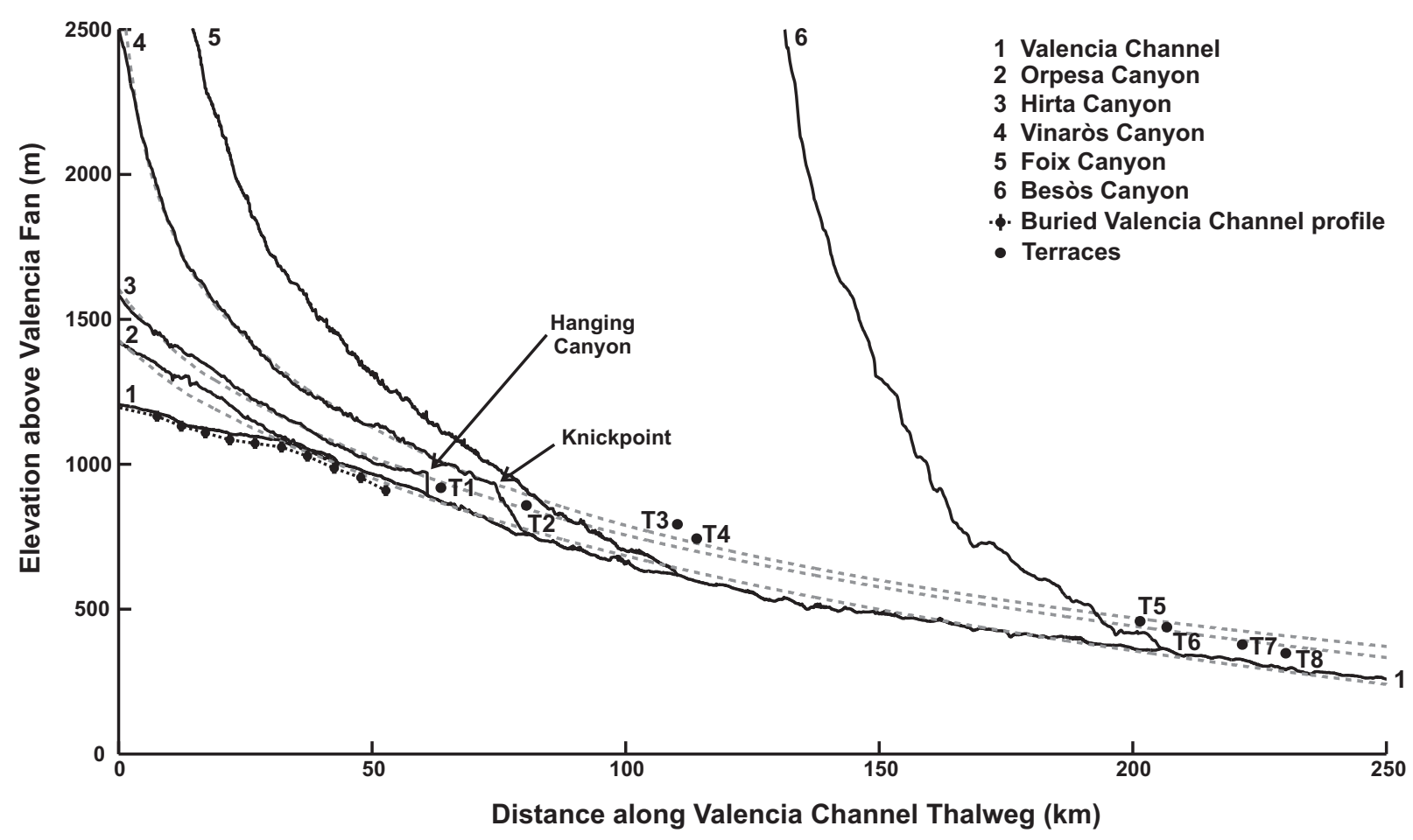

Fig.7 

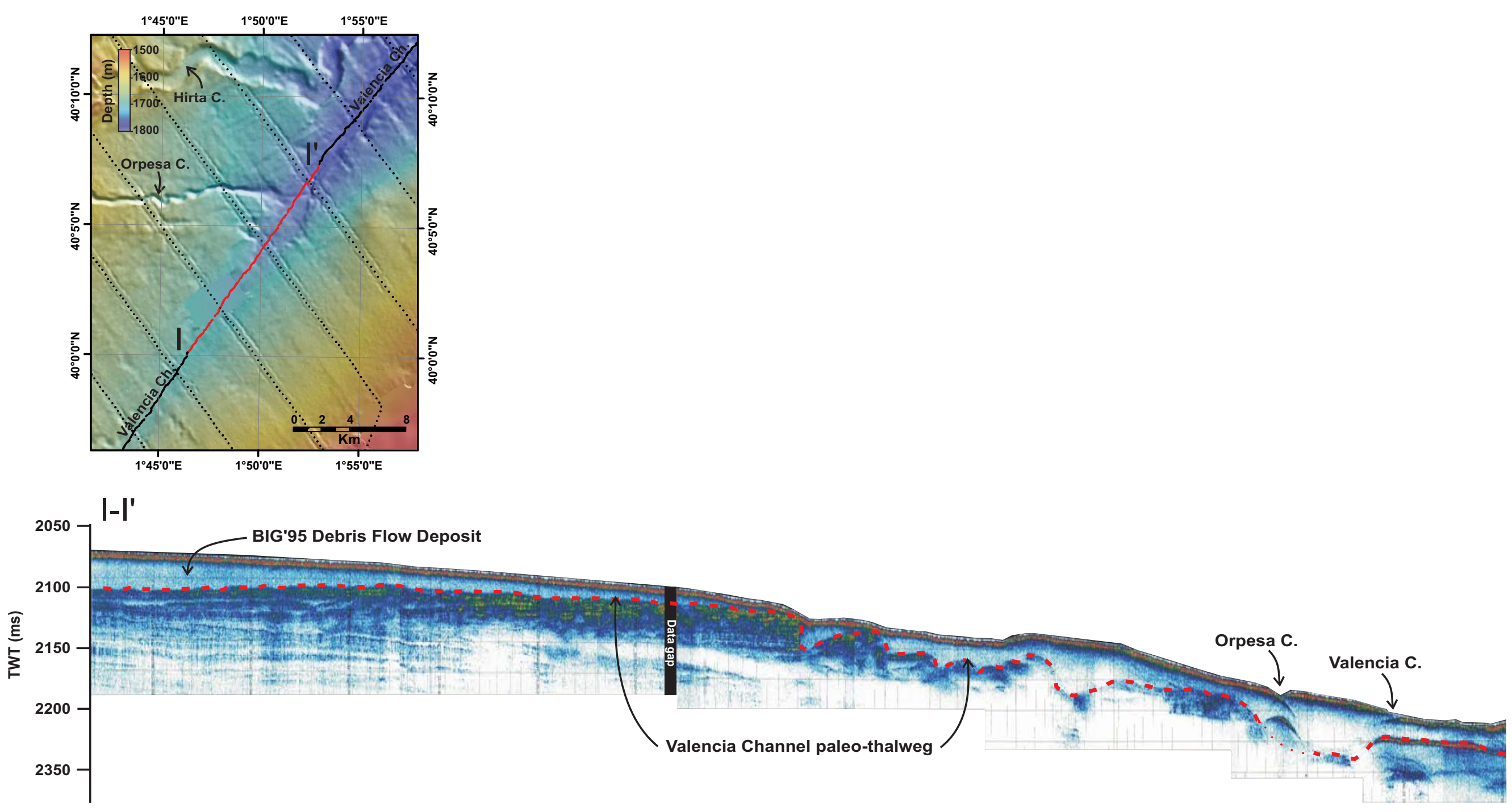

Fig.8 
a. Upstream control

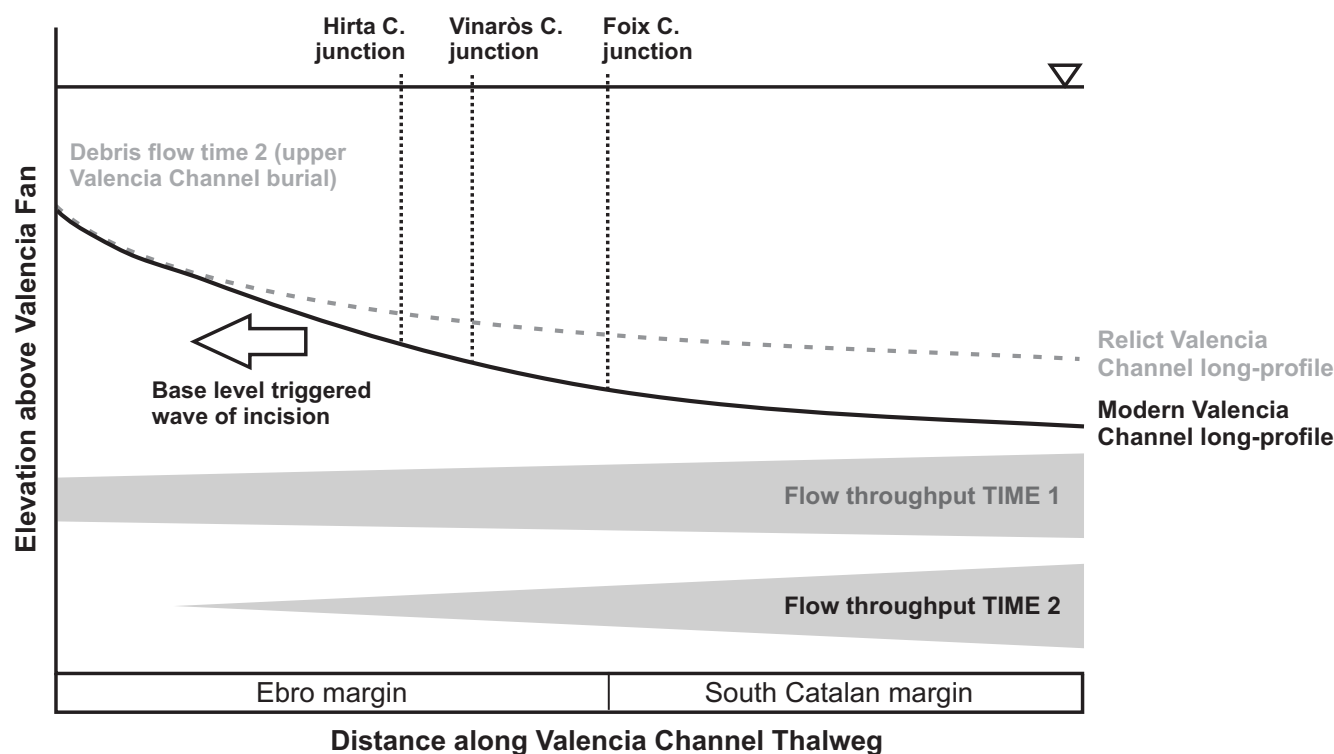

b. Downstream control

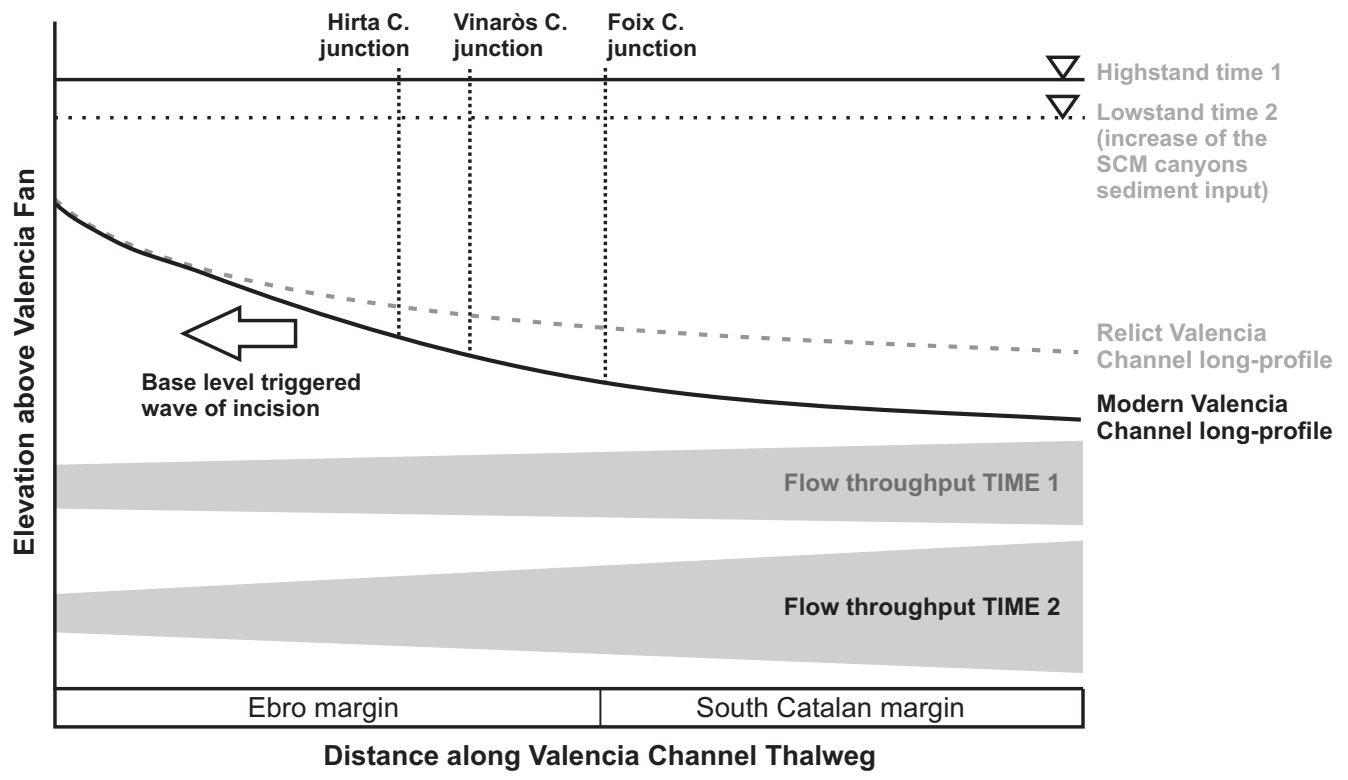

Fig.9 